\title{
The weekend effect within and downwind of Sacramento - Part 1: Observations of ozone, nitrogen oxides, and VOC reactivity
}

\author{
J. G. Murphy ${ }^{1, *}$, D. A. Day ${ }^{1, * *}$, P. A. Cleary ${ }^{1, * * *}$, P. J. Wooldridge ${ }^{1}$, D. B. Millet ${ }^{2, * * * *}$, A. H. Goldstein ${ }^{2}$, and \\ R. C. Cohen ${ }^{1,3}$ \\ ${ }^{1}$ University of California at Berkeley, Department of Chemistry, USA \\ ${ }^{2}$ University of California at Berkeley, Department of Environmental Science, Policy and Management, USA \\ ${ }^{3}$ University of California at Berkeley, Department of Earth and Planetary Sciences, USA \\ * now at: Department of Chemistry, University of Toronto, Canada \\ ** now at: University of California at Davis, Land, Air and Water Resources Department, USA \\ **** now at: University of Pennsylvania, Department of Chemistry, USA \\ ${ }^{* * * *}$ now at: Harvard University, Department of Earth and Planetary Sciences, USA
}

Received: 30 October 2006 - Published in Atmos. Chem. Phys. Discuss.: 16 November 2006

Revised: 1 August 2007 - Accepted: 1 August 2007 - Published: 16 October 2007

\begin{abstract}
Day-of-week patterns in human activities can be used to examine the ways in which differences in primary emissions result in changes in the rates of photochemical reactions, and the production of secondary pollutants. Data from twelve California Air Resources Board monitoring sites in Sacramento, CA, and the downwind Mountain Counties air basin are analyzed to reveal day of week patterns in ozone and its precursors in the summers of 1998-2002. Measurements of non-methane hydrocarbons are available for the summers of 2001-2003 at three of these sites and $\mathrm{NO}_{\mathrm{x}}$ at six of these sites for the full time period. This routine monitoring data is complemented by data sets of ozone and nitrogen oxide concentrations obtained in the summers of 2001 and 2003 at three sites in the region and comprehensive measurements of VOC reactivity at two sites in 2001. Daytime concentrations of nitrogen oxides $\left(\mathrm{NO}_{\mathrm{x}} \equiv \mathrm{NO}+\mathrm{NO}_{2}\right)$ are approximately $35 \%$ lower on weekends at all the sites, whereas the VOC reactivity changes by less than $10 \%$. All six sites in the Sacramento Valley have higher 8-h maximum average ozone on the weekend and are more likely to exceed the national standard of $85 \mathrm{ppb}$ on the weekend. In contrast, all the sites in the Mountain Counties are less likely to exceed the federal ozone standard on the weekend. Analysis of the day-of-week trends in odd oxygen show that the weekend effect of ozone within Sacramento is strongly influenced by NO sources close to the monitoring sites. This suggests that ozone measurements from monitoring sites close to highways, including two rural locations, may not be representative of the regional abundance, and lead to underestimates of long term exposure for humans and ecosystems.
\end{abstract}

Correspondence to: R. C. Cohen

(rccohen@berkeley.edu)

\section{Introduction}

Day-of-week differences in meteorology and the chemical composition of the atmosphere have been frequently observed and attributed to the influence of humans on their environment (Ashworth, 1929; Cleveland et al., 1974; Gordon, 1994; Beirle et al., 2003). Many analyses have shown that in urban areas in North America and Europe, concentrations of ozone, a principal component of photochemical smog, maximize on the weekend, when emissions of its anthropogenic precursors, nitrogen oxides $\left(\mathrm{NO}_{\mathrm{x}} \equiv \mathrm{NO}+\mathrm{NO}_{2}\right)$ and volatile organic compounds (VOC), are lowest (Jacobson, 1975; Elkus and Wilson, 1977; Karl, 1978; Pryor and Steyn, 1995; Vukovich, 2000; Pont and Fontan, 2001; Pun et al., 2003). In contrast, at other sites, mainly those in rural areas or regions with high biogenic VOC emissions, ozone is at a minimum on the weekend (Cleveland and McRae, 1978; Altshuler et al., 1995; Husar, 1998; Heuss et al., 2003). Some analyses that grouped data according to meteorological variables have shown that the sign of the weekend effect depends on whether meteorological conditions result in rapid ozone production (Bronnimann and Neu, 1997; Paschalidou and Kassomenos, 2004). Recent work has assessed the historical evolution of the weekend effect in central and southern California (Marr and Harley, 2002b; Fujita et al., 2003).

A better understanding of the processes responsible for the weekend effect can provide direct insights into the policyrelevant question of how ozone concentrations are likely to respond to changes in precursor emissions (Altshuler et al., 1995; Blanchard and Fairley, 2001). Chemical transport model simulations using emission inventories that include the day-of-week changes in the magnitude and timing

Published by Copernicus Publications on behalf of the European Geosciences Union. 
of emissions in urban areas have confirmed that there is a steeper reduction of $\mathrm{NO}_{\mathrm{x}}$ emissions compared to VOC emissions on weekends, and that when these $\mathrm{NO}_{\mathrm{x}}$ reductions occur in $\mathrm{NO}_{\mathrm{x}}$-saturated (VOC-limited) locations, they promote the production of ozone (Marr and Harley, 2002a; Yarwood et al., 2003; Vukovich and Scarborough, 2004). Predictions from a recent modeling representation of a four-day period on the Iberian peninsula are consistent with observations of higher weekend ozone in urban areas, and lower ozone in regions downwind (Jimenez et al., 2005). However, most prior analyses have not included the detailed $\mathrm{NO}_{\mathrm{x}}$ and VOC measurements, in both $\mathrm{NO}_{\mathrm{x}}$-saturated and $\mathrm{NO}_{\mathrm{x}}$-limited environments, that are essential for direct tests of mechanistic hypotheses. Those datasets that do exist are primarily short term, making it difficult to use observations to separate variability due to emissions from that caused by meteorological variability.

The factors which have been hypothesized to explain the weekend effect in urban areas include (California Air Resources Board, 2003):

1. ozone titration - less suppression of ozone by lower $\mathrm{NO}_{\mathrm{x}}$ emissions on weekend mornings

2. increased weekend emissions - different activity patterns on the weekend actually generate more $\mathrm{O}_{3}$ precursors

3. aerosol and UV radiation - more of the photons required to initiate ozone production reach the Earth's surface on weekends because of reduced aerosol concentrations

4. $\mathrm{NO}_{\mathrm{x}}$ timing - weekend traffic patterns result in more $\mathrm{NO}_{\mathrm{x}}$ being available during times of high photochemical productivity resulting in more efficient instantaneous ozone production $\left(\mathrm{P}\left(\mathrm{O}_{3}\right)\right)$

5. carryover at the surface - heavier traffic on Friday and Saturday nights results in a greater availability of $\mathrm{O}_{3}$ precursors at the surface on weekend mornings

6. carryover aloft - large amounts of ozone and precursors persist above the nighttime boundary layer and mix down to the surface the following day in such a way that weekend concentrations are higher in urban areas

7. $\mathrm{NO}_{\mathrm{x}}$ dependence of $\mathrm{P}\left(\mathrm{O}_{3}\right)$ - lower $\mathrm{NO}_{\mathrm{x}}$ on weekends in $\mathrm{NO}_{\mathrm{x}}$-saturated areas leads to more rapid ozone production

In this paper, we present observations of the day-of-week dependences of maximum 8 -h average $\mathrm{O}_{3}$ concentrations, and exceedances of the 8 -h standard $(85 \mathrm{ppb})$ from urban sites in the Sacramento Valley (SV) and more rural sites in the Mountain Counties (MC) air basins of central California between 1998 and 2002. The topography of the region ensures that regular diurnal flow patterns persist (Zhong et al., 2004) and that datasets from entire summers can be treated in a statistically meaningful way without meteorological filters. Additionally we use measurements of $\mathrm{NO}, \mathrm{NO}_{2}$, and volatile organic compounds (VOC) to probe the photochemical environment for ozone production. The California Air Resources Board routinely monitors $\mathrm{O}_{3}, \mathrm{NO}$, and $\mathrm{NO}_{2}$ at urban sites in the Sacramento Valley and $\mathrm{O}_{3}$ at sites in the Mountain Counties. We augment these routine observations with measurements of $\mathrm{NO}_{2}$, total peroxy nitrates ( $\Sigma \mathrm{PNs}$ ), total alkyl nitrates ( $\Sigma$ ANs) and $\mathrm{HNO}_{3}$ made by thermal dissociation laser-induced fluorescence (TD-LIF) (Cleary et al., 2002; Day et al., 2002) at additional sites in the two air basins, to extend our understanding of the role of nitrogen oxides in regional ozone production. Gas chromatography measurements of speciated VOC (Lamanna and Goldstein, 1999; Rubin et al., 2006) in the SV and MC are used to assess differences in VOC reactivity with $\mathrm{OH}$ between weekday and weekend.

Simultaneous measurements of $\mathrm{O}_{3}$ and $\mathrm{NO}_{2}$ permit evaluation of the role of the first hypothesis: ozone suppression by NO emissions, both during morning rush hour and throughout the day. Direct measurements of the $\mathrm{NO}_{\mathrm{x}}$ and VOC precursors to ozone enable us to investigate the veracity of the second hypothesis. Observations of $\mathrm{PM}_{10}$ in the Sacramento Valley are used to assess the third hypothesis: the effect of varying aerosol concentrations on ozone formation. In a companion paper (J. G. Murphy et al.: The weekend effect within and downwind of Sacramento - Part 2: Observational evidence for chemical and dynamical contributions; hereafter referred to as Murphy et al., 2007b), we will extend the analysis to examine the final four hypotheses in the list above. These four hypotheses are related to the complex interplay between the emissions, non-linear photochemistry and dynamics that govern the production and distribution of ozone on the regional scale. This data set offers the unique opportunity to use the weekend effect to assess the evolution of the $\mathrm{NO}_{\mathrm{x}}$-dependence of an airmass from an urban center as it is advected toward a rural mountainous region.

The chemical coupling between ozone and $\mathrm{NO}_{\mathrm{x}}$ results in non-linear relationships at concentrations of atmospheric relevance. The interconversion of $\mathrm{O}_{3}, \mathrm{NO}$ and $\mathrm{NO}_{2}$ occurs primarily through the following two reactions which constitute a chemical null cycle but act to partition the species according to the physical conditions $(T, h v)$.

$$
\begin{aligned}
& \mathrm{NO}+\mathrm{O}_{3} \rightarrow \mathrm{NO}_{2}+\mathrm{O}_{2} \\
& \mathrm{NO}_{2}+h v \stackrel{\mathrm{O}_{2}}{\longrightarrow} \mathrm{NO}+\mathrm{O}_{3}
\end{aligned}
$$

Net production of ozone occurs following the oxidation of volatile organic compounds (VOC) and $\mathrm{CO}$ by $\mathrm{OH}$ to generate peroxy $\left(\mathrm{HO}_{2}+\mathrm{RO}_{2}\right)$ radicals $(\mathrm{R} 3)$, which can oxidize $\mathrm{NO}$ to $\mathrm{NO}_{2}(\mathrm{R} 4)$. The subsequent photolysis of $\mathrm{NO}_{2}$ regenerates $\mathrm{NO}$ and produces an $\mathrm{O}\left({ }^{3} \mathrm{P}\right)$ atom which combines with $\mathrm{O}_{2}$ to form ozone (R2). The rate of ozone production is set by (R4a). At low concentrations of $\mathrm{NO}_{\mathrm{x}},\left[\mathrm{HO}_{2}+\mathrm{RO}_{2}\right]$ are independent of $\mathrm{NO}_{\mathrm{x}}$ and ozone production increases linearly with 
increases in NO. However, high concentrations of the nitrogen oxide precursors relative to the reactivity of VOC promotes the reaction of $\mathrm{OH}$ with $\mathrm{NO}_{2}$ (R5), which suppresses the hydroxyl radical, slows the production of $\mathrm{HO}_{2}+\mathrm{RO}_{2}$, and results in less ozone production. In other words, $\mathrm{RO}_{2}$ becomes inversely dependent on $\mathrm{NO}_{\mathrm{x}}$ at high concentrations of $\mathrm{NO}_{\mathrm{x}}$, resulting in a non-linear dependence of $\mathrm{O}_{3}$ production on $\mathrm{NO}_{\mathrm{x}}$ abundance. At low concentrations of $\mathrm{NO}_{\mathrm{x}}$, peroxy radicals are lost mainly through self-reaction (R6).

$$
\begin{aligned}
& \mathrm{OH}+\mathrm{VOC} \stackrel{\mathrm{O}_{2}}{\longrightarrow} \mathrm{H}_{2} \mathrm{O}+\mathrm{RO}_{2} \\
& \mathrm{RO}_{2}+\mathrm{NO} \rightarrow \mathrm{RO}+\mathrm{NO}_{2} \\
& \mathrm{RO}_{2}+\mathrm{NO}+\mathrm{M} \rightarrow \mathrm{RONO}_{2}+\mathrm{M} \\
& \mathrm{OH}+\mathrm{NO}_{2}+\mathrm{M} \rightarrow \mathrm{HNO}_{3}+\mathrm{M} \\
& \mathrm{RO}_{2}+\mathrm{R}^{\prime} \mathrm{O}_{2} \rightarrow \mathrm{ROOR}^{\prime}+\mathrm{O}_{2}
\end{aligned}
$$

Figure 1 shows the qualitative behavior of the ozone production rate over a wide range of $\mathrm{NO}_{\mathrm{x}}$ concentrations and at three different VOC reactivities $\left(\equiv \Sigma k_{3}[\mathrm{VOC}]\right)$. On the left-hand side of the figure, decreasing $\mathrm{NO}_{\mathrm{x}}$ concentrations reduce $\mathrm{P}\left(\mathrm{O}_{3}\right)$ whereas changes in VOC reactivity have little effect. On the right-hand side of the figure, decreasing $\mathrm{NO}_{\mathrm{x}}$ increases $\mathrm{P}\left(\mathrm{O}_{3}\right)$ and decreasing VOC reactivity decreases $\mathrm{P}\left(\mathrm{O}_{3}\right)$. In the intermediate range, where ozone production rates are at a maximum, reductions in both VOC and $\mathrm{NO}_{\mathrm{x}}$ can be effective at reducing ozone production. Much effort is currently expended in assessing the $\mathrm{NO}_{\mathrm{x}}$ dependence of ozone production with the goal of developing emission reduction strategies that will successfully decrease ozone violations without placing unnecessary restrictions on transport and industrial activity (National Research Council, 2004). The rate of ozone production (limited by R4a) is rarely evaluated directly in the atmosphere, because peroxy radicals are extremely challenging to measure (Heard and Pilling, 2003). The relationships between ozone and other products of the associated photochemistry such as nitric acid (R5) and peroxides (R6) have been suggested as an indirect measure of the $\mathrm{NO}_{\mathrm{x}}$-dependence of ozone production in an airmass (Sillman, 1995), although the relationships predicted by models have not been extensively compared to observations. Weekday-weekend differences in precursor emissions are a nominally well-controlled experiment that allows us to test the dependence of ozone production on $\mathrm{NO}_{\mathrm{x}}$ concentration. Examining the sign and magnitude of the weekend effect in a region may help in diagnosing the $\mathrm{NO}_{x}$ regime in which the majority of ozone is produced and suggest an effective course of action.

\section{Air quality in the Sacramento region and downwind}

Sacramento and the Sierra Nevada foothills to its east have been designated by the federal Environmental Protection

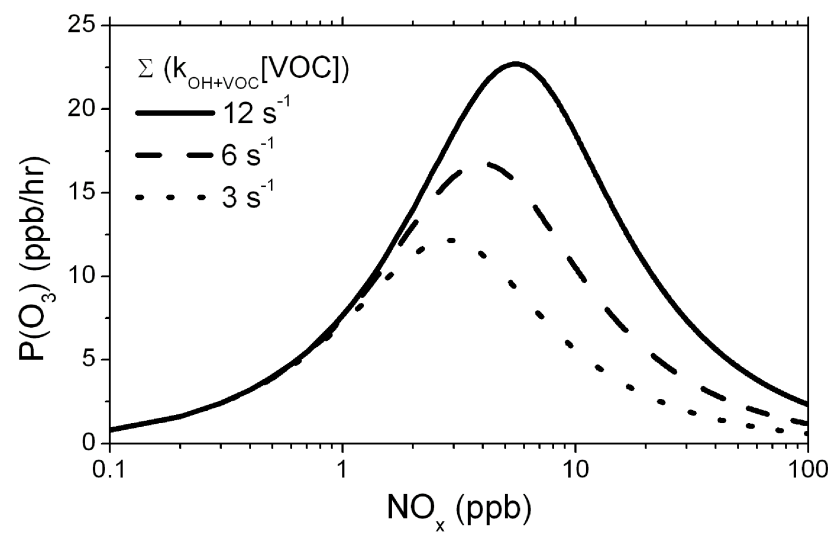

Fig. 1. The dependence of the ozone production rate $\mathrm{P}\left(\mathrm{O}_{3}\right)$ on the abundance of nitrogen oxides $\left(\mathrm{NO}_{\mathrm{x}}\right)$ at three different VOC reactivities. As the VOC reactivity is increased, the concentration at which $\mathrm{O}_{3}$ production becomes $\mathrm{NO}_{\mathrm{x}}$-saturated is higher. Increasing VOC reactivity increases $\mathrm{O}_{3}$ production where $\mathrm{NO}_{\mathrm{x}}$ is high but has a small effect when production is $\mathrm{NO}_{\mathrm{x}}$-limited. The exact quantities obtained depend on the production and loss rates of $\mathrm{HO}_{\mathrm{x}}$ which for this calculation are set to $2.25 \mathrm{ppb} \mathrm{h}^{-1}$ (a reasonable value based on production from the photolysis of ozone and formaldehyde).

Agency as a 'serious' non-attainment region that will require one of the latest attainment deadlines in the United States for the amended air quality standards, due to the severity of the problem. Violation of the 1997 National Ambient Air Quality Standard in ozone occurs when the 3-year average of the fourth highest daily maximum 8-h ozone concentration measured at a monitor equals or exceeds $85 \mathrm{ppb}$. The Clean Air Act requires each state to develop a State Implementation Plan (SIP) to attain the standard by a deadline set by the federal EPA. Strong sunlight, high temperatures, significant $\mathrm{VOC}$ and $\mathrm{NO}_{\mathrm{x}}$ emissions from mobile sources, and biogenic emissions of reactive VOC from vegetation in the Sierra foothills combine to generate optimal conditions for rapid photochemical ozone production in the region. The state agency in charge of monitoring air quality and compiling the SIP, the California Air Resources Board (CARB), has divided the region into two distinct air basins, the populous, low elevation Sacramento Valley, and the more rural, high elevation Mountain Counties (Fig. 2). While the geographical extent of the MC extends further south and north along the western slope of the Sierra Nevada, the analysis presented in this paper is limited to those sites likely to be influenced by the Sacramento urban area. We include six sites in the Sacramento Valley Air Basin: T Street, Del Paso, North Highlands, Roseville, Folsom and Elk Grove and six sites in the Mountain Counties Air Basin downwind of Sacramento: Cool, Colfax, Placerville, White Cloud, Jackson and a non-CARB site, the University of California Blodgett Forest Research Station (UC-BFRS). Shorter term data sets with more comprehensive chemical measurements were acquired 


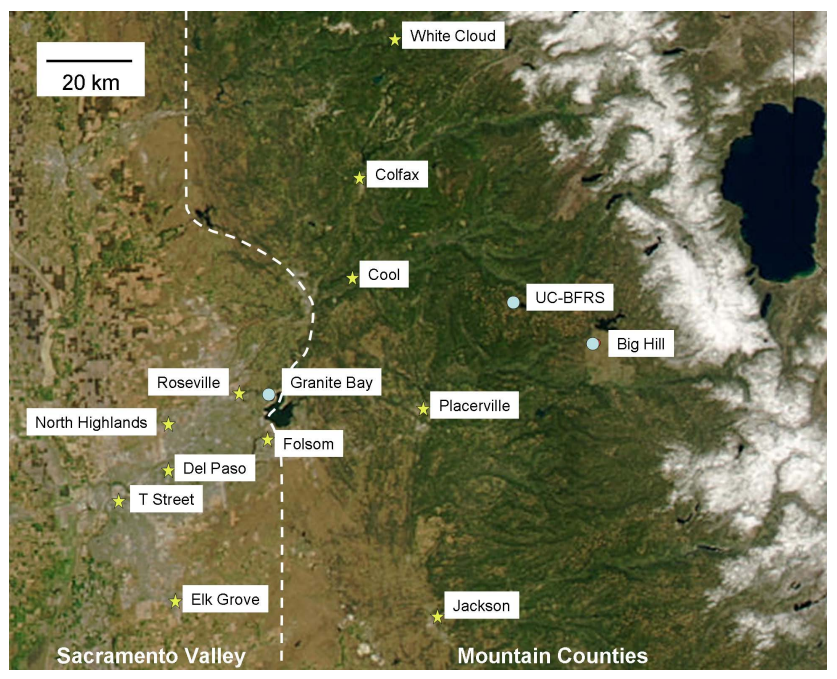

Fig. 2. The location of the monitoring sites in the Sacramento Valley and Mountain Counties (separated by the dashed line) used in this analysis.

by UC Berkeley researchers at two additional sites: Granite Bay (July-September 2001) and Big Hill (March 2003March 2004) and are used to inform our analysis of the longer term data sets.

Over the past twenty years, both air basins have exceeded the federal 8-h ozone standard between 15 and 75 days each year (CARB). Accurate comparisons of basin-wide trends are complicated by frequent changes to the number and location of active monitoring sites. Figure 3 shows the 8-h maximum air quality statistic ( 3 year average of 4 th highest value) for the CARB sites included in this analysis. The trace along the top of the gray area shows the statistic for the entire air basin while the individual sites are identified in the years for which adequate data exists. Before 1992, only the Del Paso and North Highlands sites have data, and these sites suggest a marked reduction in extreme ozone events between 1986 and 1991. Currently Folsom has the highest 8-h average maximum ozone concentrations in the Sacramento Valley region. None of the Mountain Counties sites examined in this analysis was established prior to 1992, yet the region likely had an existing air quality problem by the time routine monitoring at these sites began. Cool and Placerville have the highest 8-h maximum ozone concentrations among the Mountain Counties sites considered. Both air basins and all of the individual sites in the region except $\mathrm{T}$ Street and Elk Grove have violated the federal 8-h ozone standard every year for as long as ozone concentrations have been monitored in the region. While the SV air basin seems to have a downward trend in the 8-h air quality statistic, especially in the late 1980s, ozone concentrations in the MC air basin appear to be increasing at some sites. Historical measurements of ozone precursors are not of sufficient abundance of quality to identify the cause of these trends, though rapid growth and
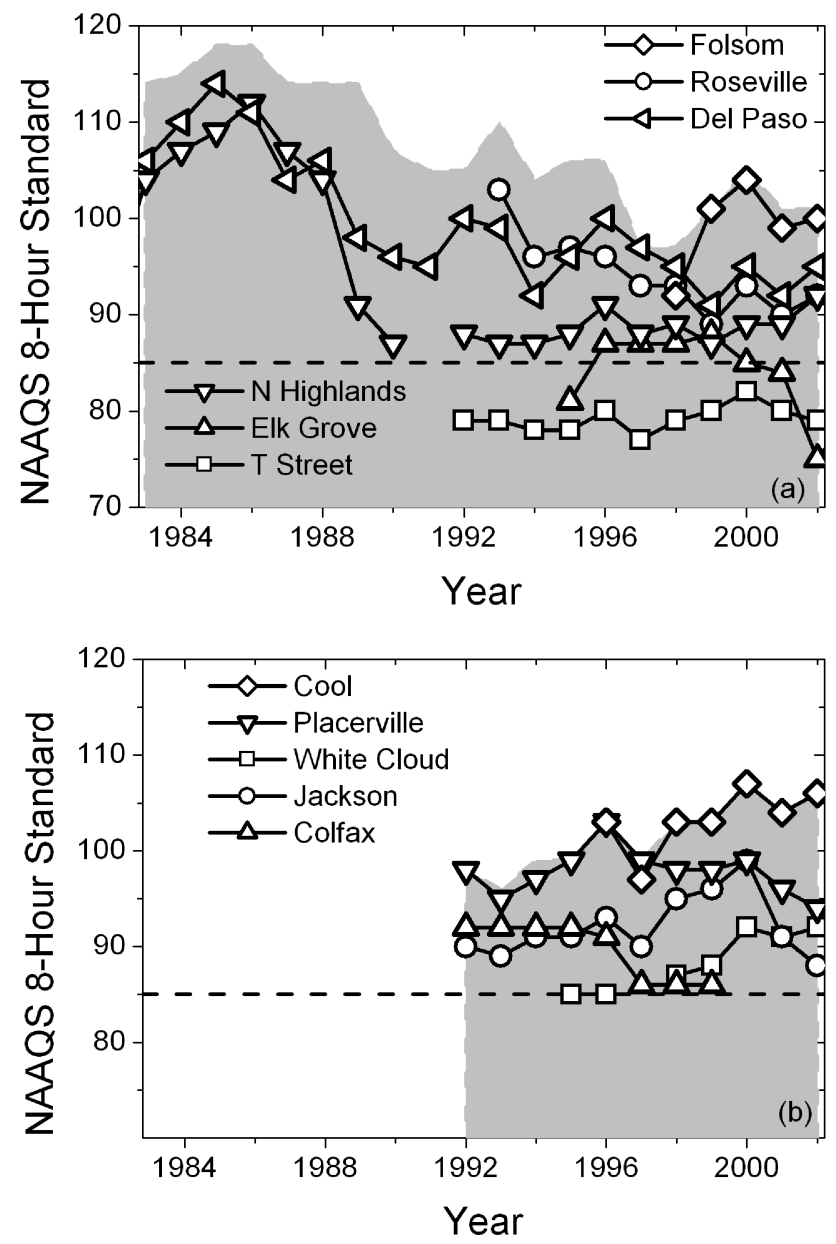

Fig. 3. 8-h maximum air quality statistic (3 year average of 4th highest value) for the individual sites in (a) the Sacramento Valley and (b) the Mountain Counties. The top of the grey area is the basin-wide statistic of the 4th highest values calculated by finding the highest 8-h maximum each day from any site in the basin.

geographical shifts in population centers likely contribute. Between 1990 and 2000, population growth in the Mountain Counties, Eldorado (25\%) and Placer (44\%), occurred more rapidly than in Sacramento County (17\%), where most of the population growth was concentrated in the eastern suburbs (State of California, 2002). While the boundaries between the air basins do not match perfectly with county boundaries used in demography, this data suggests that $\mathrm{NO}_{\mathrm{x}}$ levels rose more quickly, in a relative sense, in the suburban and rural regions to the east of Sacramento than in the urban center itself.

\section{Regional meteorology and transport}

A brief description of meteorology and transport is useful in understanding the ozone problem in the region. Exceedances of the ozone standard occur most frequently during the 
months of May through October. This time period is defined as summer in the following analysis. During the summer, skies are generally clear, temperatures are high, and precipitation events are rare. The dominant surface flow within California's Central Valley is aligned along the major N-S axis of the valley. Much of the flow enters the Valley from the west through the Carquinez Pass and splits to flow from south to north over the Sacramento Valley and from north to south through the San Joaquin Valley (Zaremba and Carroll, 1999; Zhong et al., 2004). Along the western slope of the Sierra Nevada range, daytime heating generates upslope flow from west to east, while this pattern reverses at night and air drains back down toward the valley floor (Fig. 4). The two flows couple, resulting in overall southwesterly flow of the Sacramento plume during the daytime (Carroll and Dixon, 2002; Dillon et al., 2002). Figure 5 shows local wind direction measurements at the five Sacramento Valley sites and five Mountain Counties sites with meteorological data recorded by CARB and UC Berkeley for the summers of 2000 and 2001. The roses depict the frequency of observation of a wind direction (in 15 degree bins) during the daytime (10:00-18:00) in black and nighttime (22:00-6:00) in grey. Note the narrow range of wind directions at each site. All the sites in the Sacramento Valley have predominantly southwesterly flow during the daytime and southeasterly flow at night. The local wind directions of the MC sites demonstrate why they are so likely to be influenced by emissions from Sacramento. Daytime flow at the mountainous sites is westerly or southwesterly and reverses to flow in almost exactly the opposite direction at night. Wind speeds are generally twice as fast during the daylight hours. The flow along the Sierra slopes tends to recycle airmasses: air that passed the site two hours before sunset may pass by again three or four hours after sunset if the flow changes by $180^{\circ}$. In contrast, surface measurements show that flow in the valley continually brings air from the south over Sacramento, though periods of stagnation do occur and are often associated with the highest concentrations of ozone in the city.

\section{Timing of peak ozone}

The ozone concentrations observed at a monitoring site are an integrated quantity determined by the timing and strength of the upwind precursor emissions and the rates of photochemistry and transport. Ozone production is initiated by $\mathrm{OH}$ radicals, whose concentration profile roughly follows insolation and thus maximizes near midday. Emissions of many biogenic VOC precursors to ozone production also peak in midday due to temperature or light-dependent emission rates. Anthropogenic $\mathrm{NO}_{\mathrm{x}}$ and VOC concentrations in the city are roughly constant once the daytime boundary layer has been established and morning rush hour emissions are well-mixed. Observed ozone concentrations are the integral of the upwind production and loss and therefore often peak an hour or two

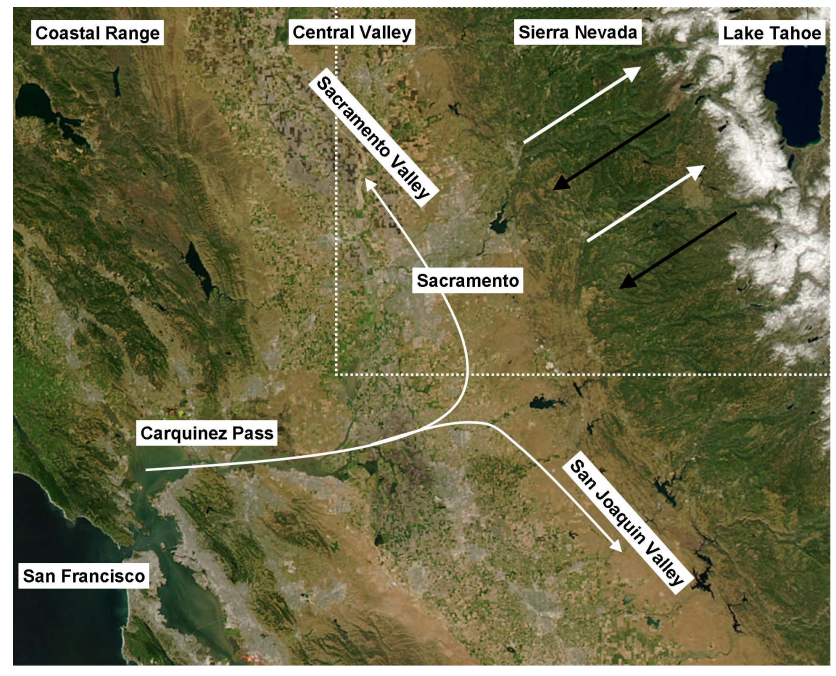

Fig. 4. Predominant meteorological regime that persists in Central California during the summer months with daytime upslope flow (white arrows) and nighttime downslope flow (black arrows). The dotted outline represents the area of interest shown in Fig. 2.

after noon in areas of efficient photochemical production. The maximum 8-h daily average and the central hour (median time of the eight hour period) of this occurrence were calculated for each site from May-October 1998-2002. The central hour of the 8-h maximum was usually also the hour of the maximum concentration on that day. In the Sacramento Valley, airmasses take roughly two or three hours to move from south to north over the city, and the central hour of the maximum usually occurs at 14:00 or 15:00. For the urban and suburban sites in the Sacramento Valley, the central hour of the 8-h maximum occurs between 13:00 and 16:00 over 95\% of the time. Concentrations at Elk Grove tend to peak on the earlier side of that range, which suggests that the precursors required for rapid ozone production are not available upwind of that site. Based on local wind speed and direction, and the timescale of ozone production, "upwind" corresponds to at least $15 \mathrm{~km}$ southwest of Elk Grove. The other factor controlling the timing of peak ozone at urban sites is rush hour emissions of nitric oxide, which titrate ozone locally in the early morning and evening. Even on days where rapid photochemical ozone production does not occur, maximum ozone is observed during midday because the higher boundary layer and a respite from rush hour traffic reduce the effects of titration from local NO sources via (R1). The effects of ozone titration by $\mathrm{NO}$ emissions will be discussed further in Sect. 7.

In contrast to the timing of the ozone maxima in the SV sites, which are consistent with efficient local production, the central hour of the 8-h maximum at the Mountain Counties sites occurs later and with greater variability. The timing of the ozone peak at these sites is governed by transport and depends on the site's proximity to the urban source of 

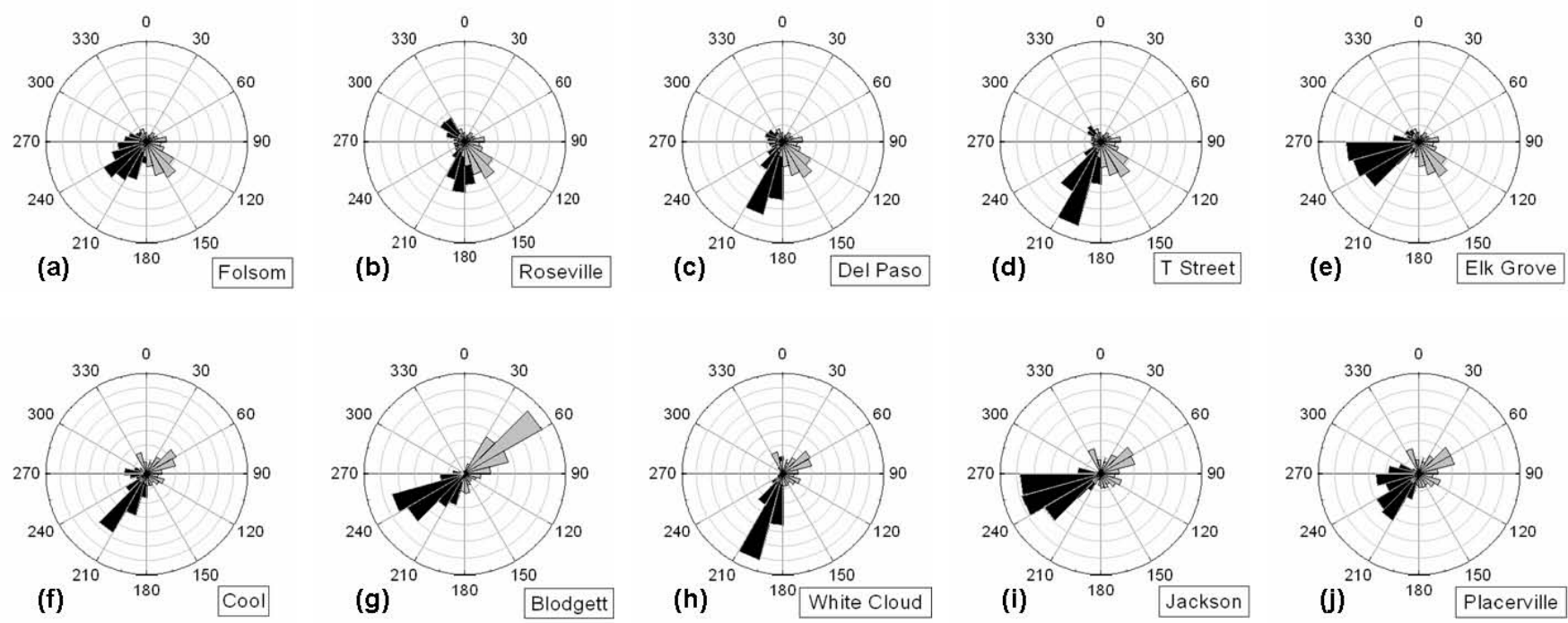

Fig. 5. Wind roses depicting the frequency of observed daytime (10:00-18:00, black) and nighttime (22:00-6:00, grey) wind direction (rings are spaced by $5 \%$ with the outer ring representing $30 \%$ of the observations. (a-e) are sites in the Sacramento Valley and (f-i) are sites in the Mountain Counties.

precursors. While peak concentrations of $\mathrm{OH}$ and biogenic VOC emissions likely occur close to noon, the $\mathrm{NO}_{\mathrm{x}}$ and anthropogenic VOC involved in ozone production are not available until upslope flow delivers urban emissions to the region. The concentration and timing of maximum ozone at the rural sites suggests that ozone is produced both in Sacramento and in the urban plume as it is advected through the Mountain Counties. At the most remote sites, UC-BFRS and White Cloud, the diurnal cycle in ozone is less pronounced than near the city, and peak values typically occurs in the late afternoon (15:00-20:00). This timing is consistent with the transit time of the urban plume, corroborated by measurements of $\mathrm{CO}$, nitrogen oxides, and anthropogenic $\mathrm{VOC}$ at the UC-BFRS (Lamanna and Goldstein, 1999; Bauer et al., 2000; Dillon et al., 2002; Day, 2003). Days on which peak ozone concentrations occur in the early morning hours can be roughly equated with days when the urban plume does not reach the site later that day. The peak values observed during early morning are much lower than those that occur in the late afternoon. For White Cloud and the UC-BFRS, the urban plume arrives on more than $80 \%$ of the days from May to October. Thus improvements to air quality in the Sacramento Valley and Mountain Counties are likely to require controls on the emissions of urban precursors to ozone production. The Mountain Counties will not be able to achieve significant improvements in its own air quality through local emission reductions alone because the impact of the upwind Sacramento sources is so dominant.

\section{The weekend effect in the Sacramento region}

Because monitoring sites are predominantly located in populous areas where primary pollutants and human exposure to them is maximized, most discussion of the weekend effect relates to high $\mathrm{NO}_{\mathrm{x}}$ environments with less attention focused on regions downwind. Many different metrics have been used to assess ozone and a "weekend effect" can depend on which data are chosen for analysis. Because ozone is a secondary pollutant that is relatively long-lived compared to its precursors, and because frequency distributions of ozone have a tail at high concentrations that is particularly important in regulatory contexts, averages often mask important features. Research has generally identified a weekend effect more readily when focusing solely on high percentiles, exceedance events or anything that concentrates on the extremes (Cleveland et al., 1974). We focus on the maximum 8-h average as a policy-relevant quantity that has been shown to have weekday-weekend differences in a variety of photochemical environments (Heuss et al., 2003).

Using archived hourly ozone measurements during the summers of 1998-2002 from the twelve sites listed above, and attributing data between midnight and $7 \mathrm{am}$ to ozone production from the previous day (a necessary consideration only at the remote sites), the maximum 8-h average ozone concentration was found for each day. The frequency of exceeding the federal 8-h air quality standard for ozone was then calculated separately for weekdays and weekends. Compared to the rural sites, most urban sites have a lower rate of exceeding the federal eight hour ozone standard and are more likely to do so on the weekend (Fig. 6). Folsom and Cool seem to be ideally located to experience prolonged 


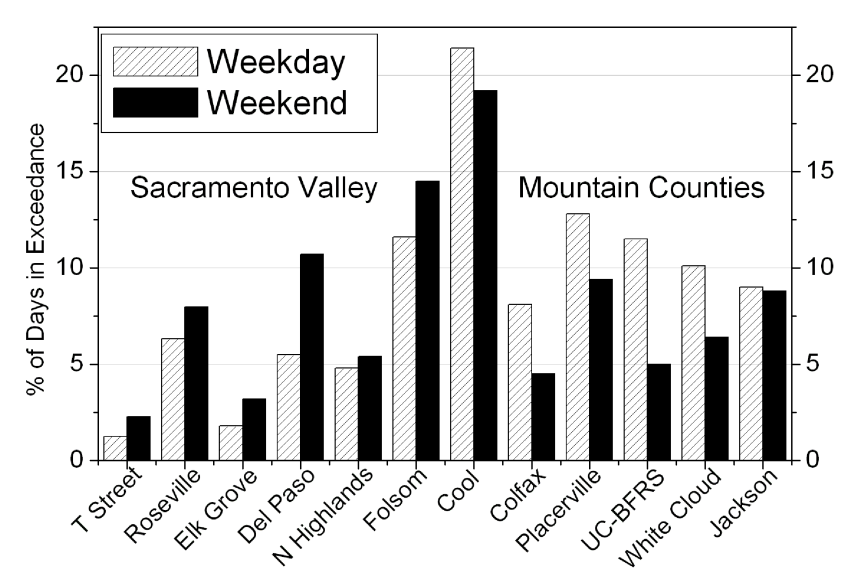

Fig. 6. Percent of days on weekends (Sat-Sun) or weekdays (MonFri) for which a particular site exceeded the federal 8-h ozone standard for May-October 1998-2002. The six sites on the left are located in the SV while the six sites on the right are in the MC.

periods of high ozone concentrations, suggesting that they sit within or downwind of regions in which ozone is efficiently produced. The sign of the weekend effect changes near the interface between the two air basins. The six MC sites all have improved air quality on the weekends, but in general they are more likely to exceed the ozone standard than any of the urban sites. Local wind observations at Jackson suggest that it is not impacted by Sacramento emissions under normal flow patterns but may receives anthropogenic emissions from the Interstate 5 corridor and possibly Stockton (2003, pop. 270000 ) about $50 \mathrm{~km}$ to the west.

\section{Day-of-week trends in $\mathrm{O}_{3}, \mathrm{NO}_{\mathrm{x}}$ and VOC}

It is instructive to separate data from each day of the week to learn how the contributing effects of emissions, and subsequent production, transport, and losses play out in influencing the trends. Day-of-week averages for the summers of 1998-2002 are calculated for 8-h maximum ozone, and for daytime $\mathrm{NO}_{\mathrm{x}}$ and $\mathrm{VOC}$ concentrations, the precursors to photochemical ozone formation. Figure 7a shows that maximum 8-h $\mathrm{O}_{3}$ concentrations at sites in the Sacramento Valley are about $2-5 \mathrm{ppb}$ higher on Sat-Sun compared to weekdays. In contrast, sites in the Mountain Counties, Fig. 7b, have the lowest 8- $\mathrm{h} \mathrm{O}_{3}$ concentrations on Sunday and generally increase throughout the week. Data obtained at Big Hill during the summer of 2003 are also included in this figure; along with three other sites it has lower ozone on Saturday than Friday. The importance of transport and the buildup of pollution is evident in the timing of the cycles, as most sites have lower ozone on Monday than on Saturday. However, the variations in average ozone between different days of the week are smaller than the $95 \%$ confidence interval of any single day. The MC sites all have concentrations closer to the
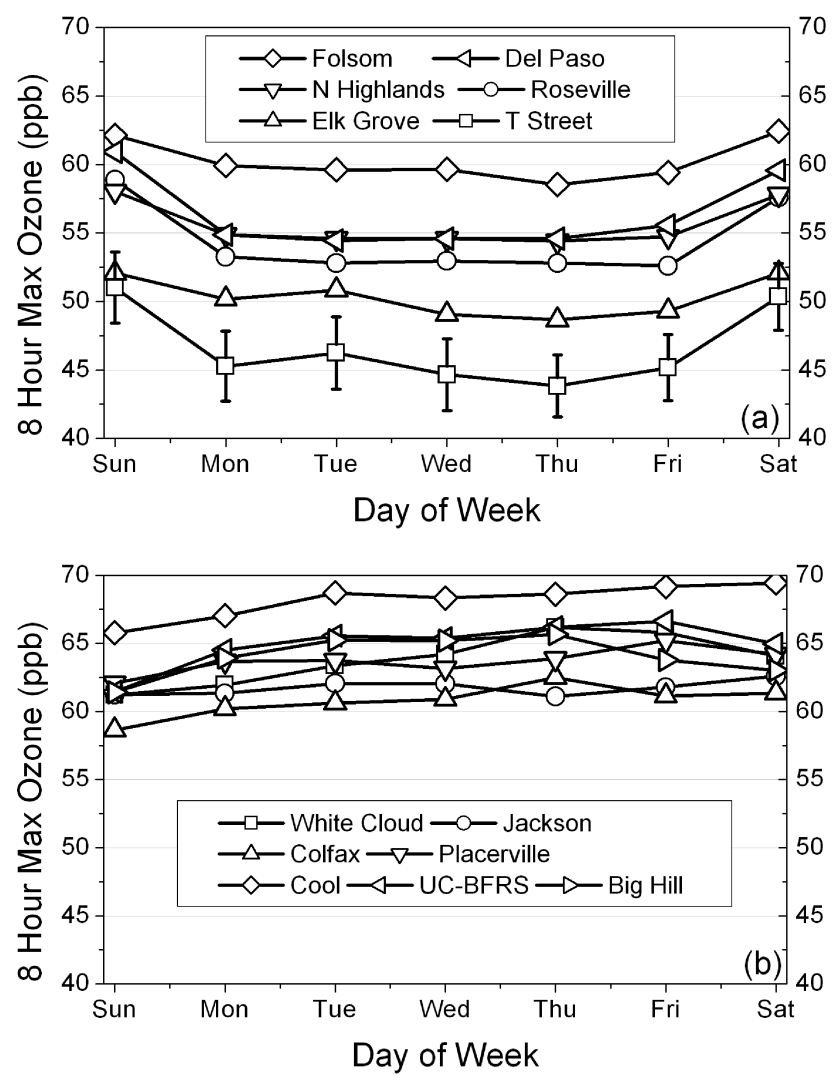

Fig. 7. Day-of-week pattern in the maximum $8-\mathrm{h} \mathrm{O}_{3}$ average in the (a) Sacramento Valley and (b) Mountain Counties. The uncertainty in any average $8 \mathrm{~h}$ maximum point, is represented by the $95 \%$ confidence interval and shown only for $\mathrm{T}$ Street for the sake of clarity. The 95\% CI for all of the points at all of the sites in Figs. 7a and b ranged between 2 and $3.5 \mathrm{ppb}$.

federal standard and thus deviations from average behavior are more likely to result in exceedances.

The main difference in $\mathrm{NO}_{\mathrm{x}}$ emissions by day of week is most evident in the concentrations observed during early morning hours, but for the purpose of ozone production, it is the abundance of $\mathrm{NO}_{\mathrm{x}}$ during the daytime hours that is critical. Thus for Sacramento Valley sites, Fig. 8a compares the mean $\mathrm{NO}_{\mathrm{x}}$ concentrations between 10:00 and 18:00, a time period when photochemical activity is high and the boundary layer is well-developed. The California Air Resources Board does not monitor $\mathrm{NO}_{\mathrm{x}}$ at any sites in the Mountain Counties so we rely on measurements of $\mathrm{NO}_{2}$, organic nitrates, and $\mathrm{HNO}_{3}$ made by UC Berkeley using TD-LIF instruments at UC-BFRS in the summer of 2001 and at Big Hill in the summer of 2003 to give an indication of day-ofweek behavior in this region. Over a timescale of minutes to hours, nitrogen oxides are photochemically processed into more oxidized reactive nitrogen species $\left(\mathrm{NO}_{\mathrm{z}} \equiv\right.$ peroxy nitrates + alkyl nitrates $\left.+\mathrm{HNO}_{3}+\ldots\right)$. The sum of all reactive nitrogen species $\left(\mathrm{NO}_{\mathrm{y}} \equiv \mathrm{NO}_{\mathrm{x}}+\mathrm{NO}_{\mathrm{z}}\right)$ is therefore a better 

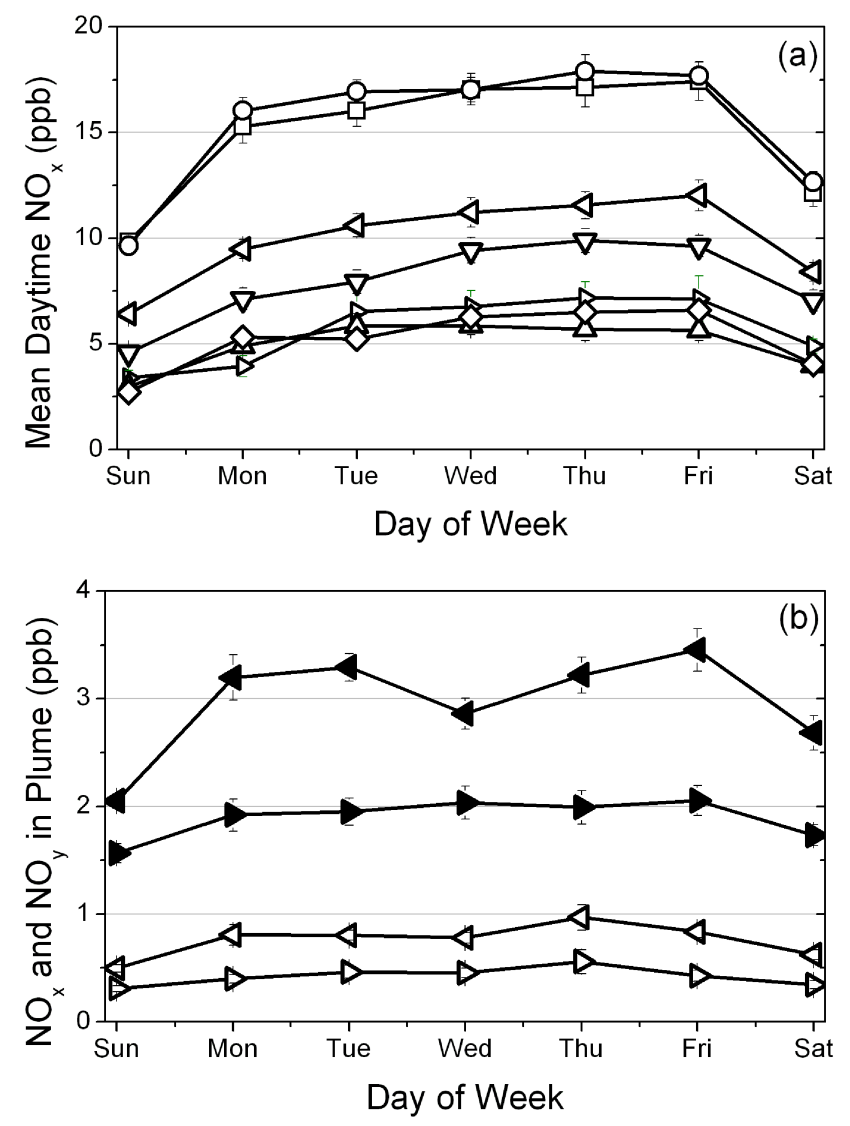

Fig. 8. Day of week pattern in the $\mathrm{NO}_{\mathrm{x}}$ concentration for the time period of maximum ozone: (a) mean $\mathrm{NO}_{\mathrm{x}}$ between 10:00 and 18:00 in the Sacramento Valley, symbols as in Fig. 7a and also including Granite Bay $(\triangleright)$, (b) mean $\mathrm{NO}_{\mathrm{x}}$ (open symbols) and $\mathrm{NO}_{\mathrm{y}}$ (filled symbols) between 12:00 and 20:00, while the urban plume is influencing the rural sites of UC-BFRS $(\triangleleft)$ and Big Hill $(\triangleright)$. Error bars represent the $95 \%$ confidence interval.

conserved species in the atmosphere than $\mathrm{NO}_{\mathrm{x}}$ alone. $\mathrm{NO}$ is less significant at rural sites and is estimated here by assuming photostationary state described in (R1)-(R3) and using measurements of $\mathrm{NO}_{2}$ and TUV estimates of $\mathrm{J}_{\mathrm{NO}_{2}}$ (Cleary et al., 2007). Figure $8 \mathrm{~b}$ shows the concentrations of both $\mathrm{NO}_{\mathrm{x}}$ and $\mathrm{NO}_{\mathrm{y}}$ at two sites in the Mountain Counties between 12:00-20:00, when ozone peaks.

Measurements of $\mathrm{NO}_{\mathrm{x}}$ are made by the California Air Resources Board using the TECO $42 \mathrm{C}$ instrument, which passes air over a heated catalyst that converts reactive nitrogen compounds to NO, which is subsequently detected using chemiluminescence. This molybdenum oxide catalyst used in these instruments is known to have a positive response to organic nitrates and nitric acid in the temperature range in which it is operated (Winer et al., 1974; Fitz, 2002), however the inlets on these instruments are not configured to sample $\mathrm{HNO}_{3}$ effectively. The $\mathrm{NO}_{2}$ concentration reported by this measurement technique is therefore likely to be biased high by the presence of organic nitrates. The extent to which the $\mathrm{NO}_{\mathrm{x}}$ concentrations are overestimated depends on the relative importance of $\mathrm{NO}_{\mathrm{z}}$ to total nitrogen oxides. In urban areas like the Sacramento Valley, where recent emissions of NO dominate, the positive interference is less important than in highly processed airmasses. Measurements of organic nitrates by TD-LIF at the UC Berkeley site of Granite Bay from JulySeptember of 2001 (Cleary et al., 2005) suggest the positive bias would be less than $30 \%$ of $\mathrm{NO}_{\mathrm{x}}$, even for a $100 \%$ conversion efficiency of organic nitrates to NO by the catalyst.

Figure 8a shows the weekly cycle in mean daytime $\mathrm{NO}_{\mathrm{x}}$ concentrations at sites in the Sacramento Valley for the summers of 1998-2002. Roseville is located within $200 \mathrm{~m}$ of Interstate 80 while the T Street site is in the downtown core and less than $400 \mathrm{~m}$ north of Highway 50. The $\mathrm{NO}_{\mathrm{x}}$ observations at these sites likely represent the high end of the range of $\mathrm{NO}_{\mathrm{x}}$ concentrations present in the boundary layer over Sacramento. Lower weekend emissions result in substantially reduced concentrations, and average concentrations increase from Monday through Friday. While individual sites are located within varying proximities to emission sources, it appears that $\mathrm{NO}_{\mathrm{x}}$ increases at the sites in parallel by roughly $0.4 \mathrm{ppb} /$ day throughout the week. This suggests that $\mathrm{NO}_{\mathrm{x}}$ is building up in the city during the week and/or that the city receives air from an upwind source that also has $\mathrm{NO}_{\mathrm{x}}$ building up during the week. Similarly, the concentrations observed on Saturday are $25 \%$ higher than those observed on Sunday. Although it is unclear to what extent that reflects different emissions versus different initial conditions, it can be expected that carryover from Friday is an important factor. Traffic counts and fuel-dependent emission factors have been used to estimate the day-of-week cycle in mobile source $\mathrm{NO}_{\mathrm{x}}$ emissions in Central California (Marr and Harley, 2002a; Harley et al., 2005). These estimates indicate that emission patterns are similar Monday through Thursday, with additional late night emissions on Friday. There is a significant decrease in heavy duty diesel traffic on weekends, and total $\mathrm{NO}_{\mathrm{x}}$ emissions on Sunday are slightly lower than Saturday.

The absolute abundance of $\mathrm{NO}_{\mathrm{y}}$ and $\mathrm{NO}_{\mathrm{x}}$ at Mountain Counties sites (Fig. 8b) is much lower than in the Sacramento Valley but the weekend/weekday $\mathrm{NO}_{\mathrm{x}}$ ratio of about $65 \%$ persists throughout the region. The rural sites do not have the same trend of increasing $\mathrm{NO}_{x}$ throughout the week that the urban sites do, but the MC datasets only encompass one year of data each and synoptic scale transport patterns may mask a more general pattern of increases that might be evident if additional data were available. The rural sites have lower $\mathrm{NO}_{\mathrm{x}}$ concentrations on Sundays than on Saturdays, indicating lower emission and/or regional carryover of emissions from the previous day. These day-of-week trends confirm that increased traffic to recreational areas in the Sierra Nevada on the weekend does not dominate the $\mathrm{NO}_{\mathrm{x}}$ pattern observed at the rural sites during times of maximum ozone. It is consistent with observations at UC-BFRS that sources 


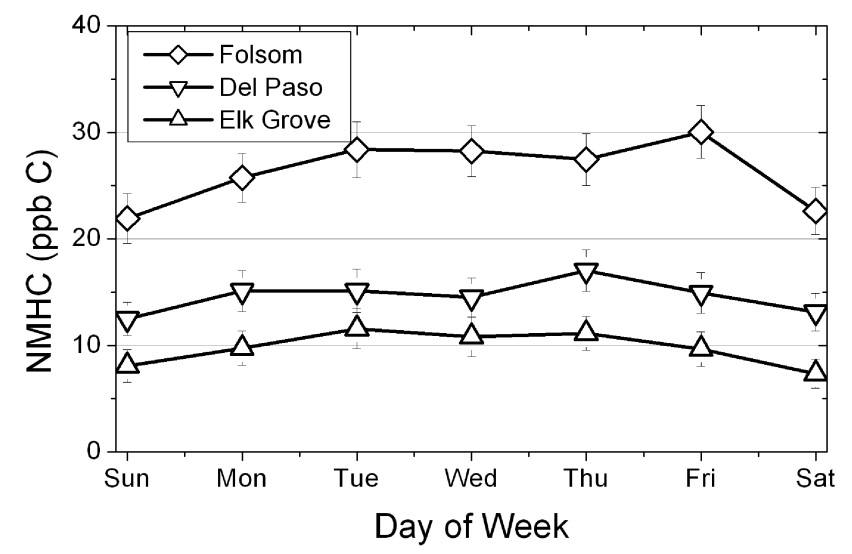

Fig. 9. Daytime NMHC measurements (ppb C) during the summers of 2001-2003 at three sites in the Sacramento Valley.

in the Sacramento Valley contribute significantly to $\mathrm{NO}_{\mathrm{x}} \mathrm{ob}-$ served downwind in the Mountain Counties sites throughout the week. Figures $7 \mathrm{a}$ and $8 \mathrm{a}$ show that higher ozone on the weekend in urban areas occurs when $\mathrm{NO}_{\mathrm{x}}$ concentrations are lower. Figures $7 \mathrm{~b}$ and $8 \mathrm{~b}$ demonstrate that in rural airmasses with less $\mathrm{NO}_{\mathrm{x}}$, the weekend effect in ozone changes sign, and fewer exceedances occur on weekends in rural areas downwind of major $\mathrm{NO}_{\mathrm{x}}$ sources.

Other studies in this region and in other urban areas have shown a similar decrease in $\mathrm{NO}_{\mathrm{x}}$ concentrations on weekends $(\sim 35 \%)$ with a smaller decrease in the abundance of the VOC precursors to ozone production (Marr and Harley, 2002b; Blanchard and Tanenbaum, 2003). CARB monitors non-methane hydrocarbons (NMHC) at three Sacramento Valley sites using a TECO 55 hydrocarbon analyzer that reports a mixing ratio of total $\mathrm{C}$ in NMHC. Figure 9 shows that as air moves from south to north and east over Sacramento (from Elk Grove to Del Paso to Folsom), the daytime concentration of NMHC increases by roughly a factor of two, due likely to both accumulating anthropogenic emissions and biogenic emissions, especially from the oak belt on the eastern perimeter of the city. Assessment of the change in ozone production rate due to changes in peroxy radical precursors would require identification and quantification of the individual compounds since the rate at which VOC are oxidized to $\mathrm{RO}_{2}\left(k_{3}\right)$ varies by orders of magnitude between species.

Speciated measurements of the VOC that contribute strongly to ozone production were made simultaneously at Granite Bay and the UC-BFRS from July-September 2001. A detailed list of VOC measured at Granite Bay can be found in Rubin et al. (2006). While the VOCs measured at the sites include a wide variety of both biogenic and anthropogenic compounds, some species that were not measured may make a non-negligible contribution to the reactivity in the airmass. Formaldehyde is likely the most important contributor to reactivity that was not included in the measurements, but its main source in the region is isoprene degradation and thus it
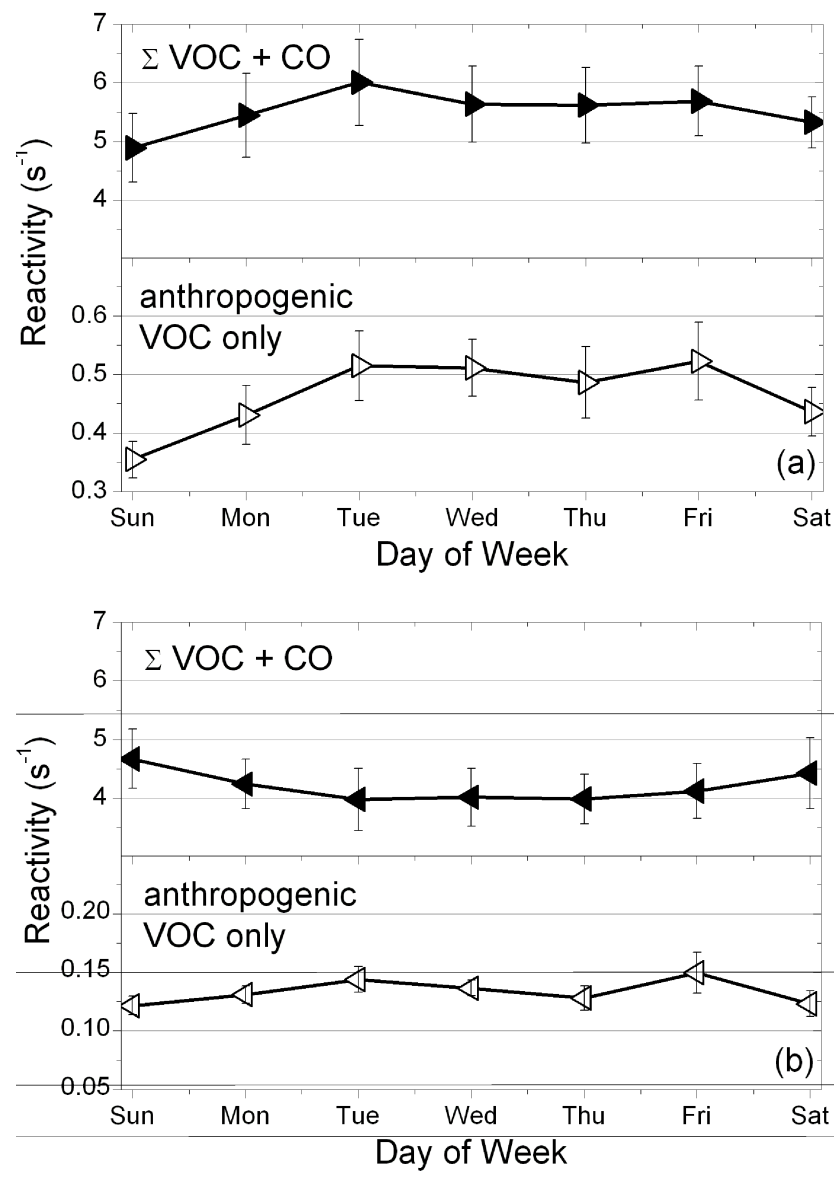

Fig. 10. Measurements of the hydrocarbon reactivity in summer 2001 (10:00-18:00) derived from the sum of all VOC measured plus $\mathrm{CO}$ (top panel), and the anthropogenic hydrocarbons only (bottom panel) at (a) Granite Bay and (b) UC-BFRS.

is not expected to have a strong day-of-week pattern. Carbon monoxide was measured by gas chromatography at UCBFRS during this time period and is considered as part of the reactivity with $\mathrm{OH}$. No $\mathrm{CO}$ measurements were made at Granite Bay, therefore measurements from the Del Paso site were used. $\mathrm{CO}$ and $\mathrm{NO}_{\mathrm{x}}$ have a common vehicular source in this urban area, and based on the observation that $\mathrm{NO}_{\mathrm{x}}$ at Del Paso is about twice as high as $\mathrm{NO}_{\mathrm{x}}$ at Granite Bay, this likely leads to a slight overestimate of $\mathrm{CO}$, but its contribution to reactivity should represent the same day-of-week pattern as other anthropogenic contributions to reactivity not measured at the site. CO contributes roughly $20 \%$ to the reactivity with $\mathrm{OH}$ at both the suburban and rural sites. Figure 10 shows the daytime $\mathrm{OH}$ reactivity $\left(\Sigma k_{3}[\mathrm{VOC}+\mathrm{CO}]\right)$ from the sum of VOC measured by GC and separately, the reactivity from a suite of VOC known to have only anthropogenic sources (not including CO). At both sites, the reactivity from anthropogenic compounds is lowest on the weekend, reflecting lower emissions. Because the weekend reduction in diesel traffic is less important for VOC emissions and because of 


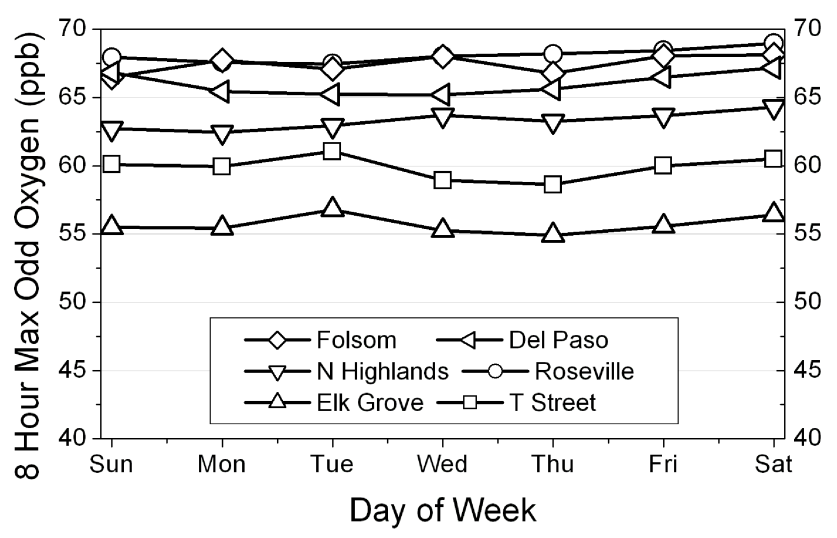

Fig. 11. Day-of-week pattern in the maximum 8-h average odd oxygen in the Sacramento Valley (for comparison with ozone data in Fig. 7a). The 95\% CI (not shown) ranged between 2.5 and 4 ppb for all of the sites.

the importance of biogenic VOC at the two sites, VOC reactivity changes by less than $10 \%$ between weekdays and weekends at both the urban and rural sites, a much smaller change than for $\mathrm{NO}_{\mathrm{x}}$. VOC at the UC-BFRS are dominated by biogenic sources, which have no known day-of-week dependence in emissions, thus the lower concentrations during the week likely reflect more rapid photochemical loss, a subject explored further in the companion paper (Murphy et al., 2007b). The observational data presented in this section show that concentrations of ozone precursors are not higher on the weekend for the Sacramento Valley and Mountain Counties Air Basins, thereby disproving hypothesis (\#2).

Total VOC reactivity is similar (within 30\%) at the urban and rural sites, likely because the anthropogenic urban emissions that are diluted and lost during transport have been replaced by biogenic emissions as the plume is advected upslope. With reference to Fig. 1, this means that a single VOC reactivity curve is qualitatively appropriate to consider $\mathrm{O}_{3}$ production as $\mathrm{NO}_{\mathrm{x}}$ varies between Granite Bay and the UC-BFRS. However, between the Sacramento suburbs and the mid-elevation pine forests, there is a significant source of isoprene, which may increase the VOC reactivity at intermediate distances. As shown in Fig. 1, the production of $\mathrm{O}_{3}$ is relatively insensitive to changes in VOC reactivity at the low $\mathrm{NO}_{\mathrm{x}}$ concentrations encountered in rural areas so this should not have a large effect on regional ozone.

\section{Differences in odd oxygen partitioning}

Because of the chemistry described in (R1)-(R4), it is important to separate the effects of interconversion from differences in ozone production rates. By defining odd oxygen as the sum of ozone and nitrogen dioxide $\left(\mathrm{O}_{\mathrm{x}} \equiv \mathrm{O}_{3}+\mathrm{NO}_{2}\right)$, we can isolate changes in production from differences in partitioning under changing $\mathrm{NO}_{\mathrm{x}}$ regimes. Figure 11 shows the day-of-week pattern for total odd oxygen at Sacramento Valley sites. The urban sites no longer have significantly higher maximum 8-h averages on the weekends. The geographic pattern becomes more clear: as the air moves from south to north over the city, emissions of $\mathrm{NO}$ are photochemically processed by reaction with $\mathrm{O}_{3}$ and $\mathrm{RO}_{2}$ into odd oxygen. Thus the sites in the northeast part of the Sacramento urban area have higher odd oxygen because the emissions of $\mathrm{NO}_{\mathrm{x}}$ and VOC from the city have had more time to be processed. The different day-of-week behavior between ozone and odd oxygen suggests that in the Sacramento region, varying degrees of interconversion of ozone to $\mathrm{NO}_{2}$ by mobile source emissions of $\mathrm{NO}_{\mathrm{x}}$ makes an important contribution to the weekend effect.

The counterpart to Fig. 11 could not be made for the Mountain Counties due to the lack of routine $\mathrm{NO}_{\mathrm{x}}$ measurements in that region. $\mathrm{NO}_{2}$ at these rural sites is likely to be quite small compared to ozone, and is unlikely to have a large influence on odd oxygen patterns. If the day-of-week trends observed at the UC-BFRS and Big Hill hold throughout the region, the combination of lower $\mathrm{NO}_{2}$ and lower ozone on the weekend would result in total odd oxygen minimizing on weekends. This pattern of low $\mathrm{O}_{3}$ associated with low $\mathrm{NO}_{\mathrm{x}}$ is consistent with the majority of ozone observed in the region being produced under $\mathrm{NO}_{\mathrm{x}}$-limited conditions. However, the interconversion of odd oxygen by fresh $\mathrm{NO}_{\mathrm{x}}$ emissions may still influence ozone observations at sites in the Mountain Counties. With reference to Fig. 2, Colfax and Placerville are closer to the region of efficient ozone production than the respective downwind sites of White Cloud and the UC-BFRS, but the 8-h maximum ozone at the closer sites is actually lower by a few ppb for each pair. Because the Colfax and Placerville monitoring sites are located within $300 \mathrm{~m}$ of Interstate 80 and Highway 50 respectively, it is likely that $\mathrm{NO}_{2}$ makes a more significant contribution to odd oxygen at those sites. This suggests that monitoring sites located near major transportation routes are potentially underestimating the regional abundance of ozone, and should include $\mathrm{NO}_{2}$ measurements in order to capture the true concentration of odd oxygen and guide policy decisions. It should be emphasized that the effect of ozone suppression by NO emissions, while most evident during morning rush hour, is important throughout the day. Lower ozone concentrations can be seen throughout the day in airmasses that were likely not influenced by urban emissions during the morning rush hour. The timescale of ozone production by (R4a) is hours, whereas the timescale of suppression by (R1) is minutes. A significant proportion of the NO observed at urban (or even rural) sites located in close proximity to a major road has had time to suppress the ozone but not to affect its production. Therefore the influence of lower weekend NO emissions on ozone production rates can best be assessed by examining the behavior of odd oxygen throughout the day. This analysis shows that the suppression of ozone by NO emissions (hypothesis \#1) is an important factor in the weekend effect in ozone at urban 
sites in the Sacramento Valley. It likely has an influence on the regional scale as well, and $\mathrm{NO}_{2}$ measurements at sites in the Mountain Counties located close to highways are required to quantify the effect.

\section{The role of aerosols in the ozone weekend effect}

Marr and Harley (2002a, b) proposed that reduced concentrations of aerosol on weekends may increase ozone production by increasing the availability of UV photons required to initiate $\mathrm{HO}_{\mathrm{x}}$ production. Aerosols interact with radiation through both absorption and scattering processes. The absorption of UV radiation by aerosols acts to reduce the available number of photons, however scattering aerosol may decrease the photon flux below the aerosol layer while increasing it above. Therefore the effect of aerosols on the availability of UV radiation may be altitude dependent, but the overall effect throughout the column will be negative for absorbing aerosols. Accurate size distributions and single scattering albedo of the aerosol burden are needed for rigorous calculations of their impact on photolysis frequencies (Wendisch et al., 1996). In a modeling simulation of the 1987 Southern California Air Quality Study, Jacobson (1998) found that the effect of aerosols on photolysis frequencies depended on the relative importance of scattering and absorption. Qin et al. (2004) found that during a study of the South Coast Air Basin, scattering by $\mathrm{PM}_{10}$ aerosol was between 9-17\% lower on the weekend, but no measurements of absorption or the net effect on UV irradiance were made at any altitude.

To properly address the role of aerosols, direct measurements of the day-of-week trends in the wavelengthdependent light absorption and scattering of atmospheric aerosol are necessary, but such detailed measurements are rarely available. In the Sacramento region, summer daytime measurements of $\mathrm{PM}_{10}$ at the Del Paso and T Street monitoring sites (2001-2003) show a day-of-week pattern, with Sunday concentrations almost 30\% lower than later weekdays (Fig. 12). However, simultaneous observations of lightscattering at Del Paso, in the lower panel, show no significant day-of-week trend. Because radiation effects depend on aerosol size and composition, more specific measurements of aerosol characteristics, or of UV radiation itself, are needed to quantify the importance of the effect. Jacobson (1998) found that a simulation of a multi-day ozone episode in Southern California that did not include aerosols predicted surface ozone concentrations which were 5-8\% higher than a model run with aerosols. This suggests that a reduction in $\mathrm{PM}_{10}$ of less than $30 \%$ will likely affect surface ozone by less than 5\%. More detailed measurements of aerosol characteristics are required to quantify the influence of aerosol on ozone production and its role in the weekend effect.

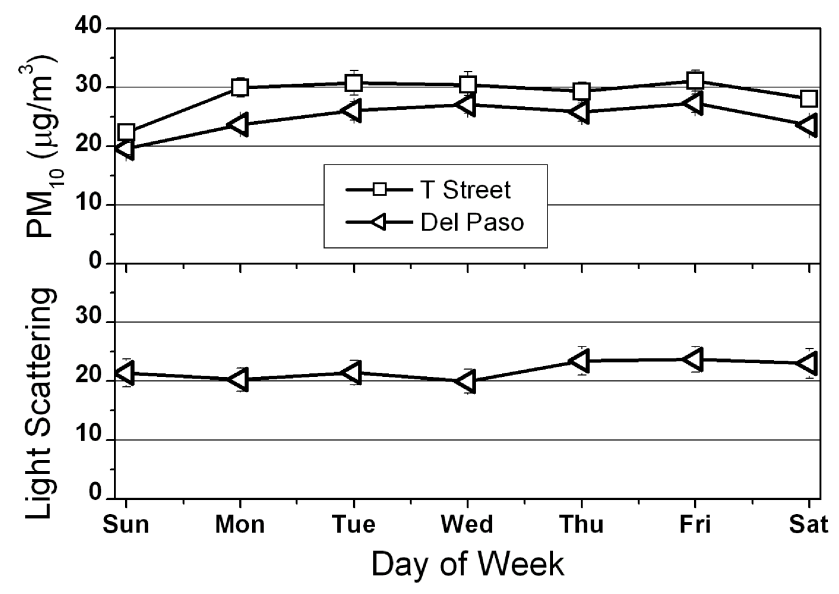

Fig. 12. Aerosol concentrations $\left(\mu \mathrm{g} / \mathrm{m}^{3}\right)$ of $\mathrm{PM}_{10}$ measured at the Del Paso and T Street monitoring sites in the Sacramento Valley. The bottom panel shows simultaneous measurements of light scattering (back scatter ratio) at the Del Paso site.

\section{Conclusions}

Day-of-week patterns in observations of ozone and its precursors at twelve sites within and downwind of the Sacramento metropolitan area from the summers of 1998-2002 have been investigated. The analysis shows that all six sites in the Sacramento Valley air basin exceed the 8-h standard more frequently on the weekend than on weekdays, whereas all six sites in the more rural Mountain Counties have worse air quality on weekdays. While previous work has identified higher weekend ozone concentrations in urban areas, and lower weekend ozone in some rural areas, this is the first analysis to use a well-characterized urban plume to follow the weekend effect in ozone over sites that differ in $\mathrm{NO}_{\mathrm{x}}$ abundance by an order of magnitude. At the same time, speciated measurements of VOC and $\mathrm{CO}$ at a suburban and rural site demonstrate that the reactivity toward $\mathrm{OH}$ changes by less than $30 \%$ throughout the urban plume and by less than $10 \%$ between weekdays and weekend at both sites. Observations of $\mathrm{NO}_{\mathrm{x}}$ and anthropogenic VOC confirm that emissions of the dominant anthropogenic precursors to ozone production are not higher on the weekend (negating hypothesis \#2). The important role that biogenic emissions play in the region means that the total VOC reactivity with $\mathrm{OH}$ has a negligible $(<10 \%)$ day-of-week pattern in both counties. Higher weekend biogenic VOC at the UC-BFRS suggests that the oxidation rate of these VOC is slower on the weekend. Observations of $\mathrm{PM}_{10}$ at two urban monitoring sites showed that lower weekend concentrations could not be directly related to an increase in photolysis frequencies for ozone-forming reactions (hypothesis \#3). More detailed measurements are required to quantify the role aerosols play in the weekend effect of ozone. 
We also show that titration by NO emissions can be an important control over the weekend effect in ozone, not only at rush hour, but throughout the day (hypothesis \#1). The analysis reveals that sites located within several hundred meters of transportation routes will have significantly depressed ozone concentrations, leading to underestimates of the average regional abundance, if the $\mathrm{O}_{3}$ concentrations are extrapolated without detailed consideration of the $\mathrm{NO}_{2}$ that is simultaneously present. Furthermore, monitoring stations that are near to NO sources are influenced by chemistry occurring on temporal and spatial scales much finer than the resolution of gridded models used to represent atmospheric photochemistry, and thus should be used with care when comparisons are made.

Because fresh $\mathrm{NO}_{\mathrm{x}}$ emissions continue throughout the day in the Sacramento region, it was necessary to examine the patterns in total odd oxygen at the sites in the Sacramento Valley. By comparing day-of-week patterns in odd oxygen to those in ozone, we showed that titration by NO is the main source of a weekend effect in ozone at the urban and suburban sites. Titration at CARB sites in the Mountain Counties is difficult to assess in the absence of $\mathrm{NO}_{\mathrm{x}}$ measurements, but clearly does not dominate the day-of-week trends because it would produce the opposite behavior to that observed.

Acknowledgements. The analysis presented here was primarily supported by NSF ATM-0138669. We gratefully acknowledge that support and the U.S. Department of Energy support for measurements at Granite Bay under contract AC03-76SF0009. Observations at UC-BFRS were supported by NSF ATM-0138669 (Cohen) and ATM-0443448 (Goldstein). We thank Megan McKay and Gunnar Schade for assistance with meteorological, ozone, and VOC data from UC-BFRS. Measurements at Big Hill were made in collaboration with the California Air Resources Board under Contract No. 01-327. We are grateful to the Eureka Union School District, Sierra Pacific Industries, and the United States Forest Service for the use of the sites.

Edited by: P. Monks

\section{References}

D. o. Finance: Revised Historical City, County and State Population Estimates, 1991-2000, with 1990 and 2000 Census Counts., State of California, 2002.

Altshuler, S. L., Arcado, T. D., and Lawson, D. R.: Weekday vs weekend ambient ozone concentrations - discussion and hypotheses with focus on Northern California, J. Air Waste Manage., 45, 967-972, 1995.

Ashworth, J. R.: The influence of smoke and hot gases from factory chimneys on rainfall, Q. J. Roy. Meteor. Soc., 55, 841-850, 1929.

Bauer, M. R., Hultman, N. E., Panek, J. A., and Goldstein, A. H.: Ozone deposition to a ponderosa pine plantation in the Sierra Nevada Mountains (CA): A comparison of two different climatic years, J. Geophys. Res., 105(D17), 22 123-22 136, doi:10.1029/2000JD900168, 2000.
Beirle, S., Platt, U., Wenig, M., and Wagner, T.: Weekly cycle of $\mathrm{NO}_{2}$ by GOME measurements: a signature of anthropogenic sources, Atmos. Chem. Phys., 3, 2225-2232, 2003, http://www.atmos-chem-phys.net/3/2225/2003/.

Blanchard, C. L. and Fairley, D.: Spatial mapping of VOC and $\mathrm{NO}_{\mathrm{X}}$-limitation of ozone formation in central California, Atmos. Environ., 35, 3861-3873, 2001.

Blanchard, C. L. and Tanenbaum, S. J.: Differences between weekday and weekend air pollutant levels in southern California, J. Air Waste Manage., 53, 816-828, 2003.

Bronnimann, S. and Neu, U.: Weekend-weekday differences of near-surface ozone concentrations in Switzerland for different meteorological conditions, Atmos. Environ., 31, 1127-1135, 1997.

California Air Resources Board: The Ozone Weekend Effect in California, CARB Planning and Technical Support Division, Sacramento, 2003.

California Air Resources Board Air Quality Database: www.arb.ca. gov/aqd/aqdpage.

Carroll, J. J. and Dixon, A. J.: Regional scale transport over complex terrain, a case study: tracing the Sacramento plume in the Sierra Nevada of California, Atmos. Environ., 36, 3745-3758, 2002.

Cleary, P. A., Wooldridge, P. J., and Cohen, R. C.: Laser-induced fluorescence detection of atmospheric $\mathrm{NO}_{2}$ with a commercial diode laser and a supersonic expansion, Appl. Opt., 41, 69506956, 2002.

Cleary, P. A., Murphy, J. G., Wooldridge, P. J., Day, D. A., Millet, D. B., Goldstein, A. H., and Cohen, R. C.: Observations of total alkyl nitrates within the Sacramento urban plume, Atmos. Chem. Phys. Discuss., 5, 4801-4843, 2005, http://www.atmos-chem-phys-discuss.net/5/4801/2005/.

Cleary, P. A., Wooldridge, P. J., Millet, D. B., McKay, M., Goldstein, A. H., and Cohen, R. C.: Observations of total peroxy nitrates and aldehydes: measurement interpretation and inference of $\mathrm{OH}$ radical concentrations, Atmos. Chem. Phys., 7, 19471960, 2007, http://www.atmos-chem-phys.net/7/1947/2007/.

Cleveland, W. S., Graedel, T. E., Kleiner, B., and Warner, J. L.: Sunday And workday variations in photochemical air pollutants in New-Jersey and New-York, Science, 186, 1037-1038, 1974.

Cleveland, W. S. and McRae, J. E.: Weekday-weekend ozone concentrations in Northeast United-States, Environ. Sci. Technol., 12, 558-563, 1978.

Day, D. A., Wooldridge, P. J., Dillon, M. B., Thornton, J. A., and Cohen, R. C.: A thermal dissociation laser-induced fluorescence instrument for in situ detection of $\mathrm{NO}_{2}$, peroxy nitrates, alkyl nitrates, and $\mathrm{HNO}_{3}$, J. Geophys. Res., 107(D6), doi:10.1029/2001JD000779, 2002.

Day, D. A.: Observations of $\mathrm{NO}_{2}$, total peroxynitrates, total alkyl nitrates, and $\mathrm{HNO}_{3}$ in the mid-Sierras and Sacramento plume using Thermal Dissociation - Laser Induced Fluorescence, University of California, 207 pp., 2003.

Dillon, M. B., Lamanna, M. S., Schade, G. W., Goldstein, A. H., and Cohen, R. C.: Chemical evolution of the Sacramento urban plume: Transport and oxidation, J. Geophys. Res., 107(D5), 4045, doi:10.1029/2001JD000969, 2002.

Elkus, B. and Wilson, K. R.: Photochemical air pollution - Weekend weekday differences, Atmos. Environ., 11, 509-515, 1977. 
Fitz, D. R.: Evaluation of $\mathrm{NO}_{\mathrm{y}}$ and Nitric Acid Measurement Methods and Collection of Ambient Data, California Air Resources Board, 2002.

Fujita, E. M., Stockwell, W. R., Campbell, D. E., Keislar, R. E., and Lawson, D. R.: Evolution of the magnitude and spatial extent of the weekend ozone effect in California's South Coast Air Basin, 1981-2000, J. Air Waste Manage., 53, 802-815, 2003.

Gordon, A. H.: Weekdays Warmer Than Weekends, Nature, 367, 325-326, 1994.

Harley, R. A., Marr, L. C., Lehner, J. K., and Giddings, S. N.: Changes in motor vehicle emissions on diurnal to decadal time scales and effects on atmospheric composition, Environ. Sci. Technol., 39, 5356-362, 2005.

Heard, D. E. and Pilling, M. J.: Measurement of $\mathrm{OH}$ and $\mathrm{HO}_{2}$ in the troposphere, Chem. Rev., 103, 5163-5198, 2003.

Heuss, J. M., Kahlbaum, D. F., and Wolff, G. T.: Weekday/weekend ozone differences: What can we learn from them?, J. Air Waste Manage., 53, 772-788, 2003.

Husar, R. B.: Seasonal and Weekly Pattern of Ozone over the OTAG Region, paper presented at Air and Waste Management Association's 90th Annual Meeting \& Exhibition, Abstr.-No.: 98-A942, 1998.

Jacobson, J. S.: Comparison of Weekend-Weekday Ozone and Hydrocarbon Concentrations in Baltimore-Washington Metropolitan Area, Atmos. Environ., 9, 1040-1040, 1975.

Jacobson, M. Z.: Studying the effects of aerosols on vertical photolysis rate coefficient and temperature profiles over an urban airshed, J. Geophys. Res., 103, 10 593-10 604, 1998.

Jimenez, P., Parra, R., Gasso, S., and Baldasano, J. M.: Modeling the ozone weekend effect in very complex terrains: a case study in the Northeastern Iberian Peninsula, Atmos. Environ., 39, 429444, 2005.

Karl, T. R.: Day of Week Variations of Photo-Chemical Pollutants in St-Louis Area, Atmos. Environ., 12, 1657-1667, 1978.

Lamanna, M. S. and Goldstein, A. H.: In situ measurements of $\mathrm{C}_{2}-\mathrm{C}_{10}$ volatile organic compounds above a Sierra Nevada ponderosa pine plantation, J. Geophys. Res., 104(D17), $21247-$ 21 262, doi:10.1029/1999JD900289, 1999.

Marr, L. C. and Harley, R. A.: Modeling the effect of weekdayweekend differences in motor vehicle emissions on photochemical air pollution in central California, Environ. Sci. Technol., 36, 4099-4106, 2002a.

Marr, L. C. and Harley, R. A.: Spectral analysis of weekdayweekend differences in ambient ozone, nitrogen oxide, and nonmethane hydrocarbon time series in California, Atmos. Environ., 36, 2327-2335, 2002b.

National Research Council: Air Quality Management in the United States, The National Academies Press, 2004.
Paschalidou, A. K. and Kassomenos, P. A.: Comparison of air pollutant concentrations between weekdays and weekends in Athens, Greece for various meteorological conditions, Environ. Technol., 25, 1241-1255, 2004.

Pont, V. and Fontan, J.: Comparison between weekend and weekday ozone concentration in large cities in France, Atmos. Environ., 35, 1527-1535, 2001.

Pryor, S. C. and Steyn, D. G.: Hebdomadal and Diurnal Cycles in Ozone Time-Series From the Lower Fraser Valley, BC, Atmos. Environ., 29, 1007-1019, 1995.

Pun, B. K., Seigneur, C., and White, W.: Day-of-week behavior of atmospheric ozone in three US cities, J. Air Waste Manage., 53, 789-801, 2003.

Qin, Y., Tonnesen, G. S.. and Wang, Z.: Weekend/weekday differences of ozone, $\mathrm{NO}_{\mathrm{x}}, \mathrm{CO}, \mathrm{VOCs}, \mathrm{PM}_{10}$ and the light scatter during ozone season in southern California, Atmos. Environ., 38, 3069-3087, 2004.

Rubin, J. I., Kean, A. J., Harley, R. A., Millet, D. B., and Goldstein, A. H.: Temperature dependence of volatile organic compound evaporative emissions from motor vehicles, J. Geophys. Res., D03305, doi:10.1029/2005JD006458, 2006.

Sillman, S.: The Use Of $\mathrm{NO}_{y}, \mathrm{H}_{2} \mathrm{O}_{2}$, and $\mathrm{HNO}_{3}$ as indicators for ozone- $\mathrm{NO}_{\mathrm{x}}$-hydrocarbon sensitivity in urban locations, J. Geophys. Res., 100, 14 175-14 188, 1995.

Vukovich, F. M.: The spatial variation of the weekday/weekend differences in the Baltimore area, J. Air Waste Manage., 50, 20672072, 2000.

Vukovich, F. M. and Scarborough, J.: 15-year simulation of ozone in Baltimore using SIPM, Atmos. Environ., 38, 4825-4837, 2004.

Wendisch, M., Mertes, S., Ruggaber, A., and Nakajima, T.: Vertical profiles of aerosol and radiation and the influence of a temperature inversion: Measurements and radiative transfer calculations, J. Appl. Meteorol., 35, 1703-1715, 1996.

Winer, A. M., Peters, J. W., Smith, J. P., and Pitts, J. N.: Response Of Commercial Chemiluminescent $\mathrm{NO}-\mathrm{NO}_{2}$ Analyzers To Other Nitrogen-Containing Compounds, Environ. Sci. Technol., 8, 1118-1121, 1974.

Yarwood, G., Stoeckenius, T. E., Heiken, J. G., and Dunker, A. M.: Modeling weekday/weekend Los Angeles region for 1997, J. Air Waste Manage., 53, 864-875, 2003.

Zaremba, L. L. and Carroll, J. J.: Summer wind flow regimes over the Sacramento Valley, J. Appl. Meteorol., 38, 1463-1473, 1999.

Zhong, S. Y., Whiteman, C. D., and Bian, X. D.: Diurnal evolution of three-dimensional wind and temperature structure in California's Central Valley, J. Appl. Meteorol., 43, 1679-1699, 2004. 